Volume 11, Nomor 1, Mei 2019, pp 166 - 175 Copyright (C) 2017 Jurnal Akuntansi Maranatha, Program Studi Akuntansi, Fakultas Ekonomi,Universitas Kristen Maranatha. ISSN 2085-8698 | e-ISSN 2598-4977. http://journal.maranatha.edu

\title{
Pengaruh Rasio Earning per Share (EPS), Return on Equity (ROE) danNet Profit Margin (NPM) pada Harga Saham (Studi pada Saham Perusahaan yang Tercatat dalam IDX30 di BEI Periode 2014-2017)
}

\author{
Yani Monalisa \\ Fakultas Ekonomi Program Studi Manajemen-Univ.Kristen Maranatha \\ (Jl. Prof. Drg. Suria Sumantri No. 65, Bandung) \\ yanimonalisa@outlook.com
}

\begin{abstract}
This study aims toanalyze the effect of earning per share (EPS), return on equity (ROE) and net profit margin (NPM) on stock price, whichare listed active in IDX30 in BEI Period 2014-2017. Data analyzed using multiple regression analysis, t-Test and F-Test with significance level of 5\%. Data have been processed by using SPSS Ver. 23 for windows. The results showed partial EPS, ROE and NPM influence on stock price and three ratios simultaneously influence stock price.
\end{abstract}

Keywords: EPS, ROE, NPM, Stock Price and IDX30

\section{Pendahuluan}

Banyaknya rasio keuangan yang ada, membuat para penganut analisis fundamental memiliki 'resep' nya masingmasing, rasio mana yang paling jitu untuk memutuskan saham mana yang akan masuk ke dalam portofolio mereka. Graham (2003) dalam bukunya The Intelligent Investor, menggunakan beberapa rasio, seperti earning per share (EPS) dan price earning ratio (PER) untuk melihat kinerja 3 perusahaan yang berjaya di masanya: General Electric, Home Depot dan Sun Microsystem. Ketiga perusahaan ini tumbuh dengan pesat, diikuti dengan harga saham yang melejit. Namun Graham berpendapat perusahaan besar tidak akan menjadi investasi besar jika para investor membayar terlalu mahal.

Menurut Atmaja (2015), rasio keuangan yang banyak dijadikan acuan para investor adalah earning per share (EPS), return on equity (ROE), price earning ratio (PER), price to book value (PBV), debt to equity ratio (DER) dan dividend yield. Keenam rasio ini banyak dijadikan acuan bagi para investor muda, yang menginginkan level aman dan optimal dalam berinvestasi di saham. Aman dalam arti kata saham pilihan mereka memiliki fundamental yang baik, sehingga aman untuk disimpan, baik jangka pendek maupun jangka panjang. Optimal dalam arti capital gain bisa maksimal, beli di bawah dan jual di atas. 
Saham-saham yang menjadi lirikan mereka umumnya dimulai dengan saham-saham yang tergabung dalam indeks LQ45. Indeks LQ45 berisi 45 perusahaan yang memiliki kriteria diantaranya masuk sebagai 60 perusahaan dengan kapitalisasi pasar terbesar selama 12 bulan terakhir dan masuk dalam 60 perusahaan dengan nilai transaksi terbesar di pasar regular selama 12 bulan terkahir. Dari daftar tersebut, Bursa Efek Indonesia (BEI) mengumumkan 45 saham LQ45. Selain LQ45, Bursa Efek Indonesia (BEI) memiliki 21 indeks lainnya, diantaranya IHSG, IDX30, Kompas100, Jakarta Islamic Index (JII), dan lain-lain.

IDX30 kurang se-populer LQ45.Namun perusahaan yang masuk dalam IDX30 merupakan 30 perusahaan yang tergabung dalam LQ45. Indeks yang diluncurkan pada tanggal 23 April 2012 ini hanya menempatkan 30 perusahaan saja, dikarenakan menurut teori portofolio, angka 30 menjadi ramuan yang pas bagi sebuah portofolio.Bursa Efek Indonesia berharap Indeks IDX30 ini dapat menjadi acuan alternatif bagi para investor.

\section{Kerangka Teoritis dan Hipotesis}

\section{Earning Per Share (EPS)}

Ratio EPS banyak menjadi acuan bagi para investor dalam menentukan saham mana yang akan dipilih. Budi Frensidy (2016) mengatakan bahwa PER dan PBV banyak dijadikan tolak ukur dalam pemilihan saham bagi investor.Berhubung penelitian ini melihat dampak ratio terhadap harga saham, maka rasio yang memiliki unsur price, tidak diikutsertakan.Penelitian lebih difokuskan pada rasio yang turut membentuk PER, yaitu rasio EPS.

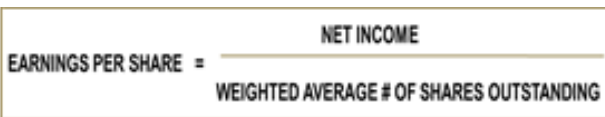

Rasio ini didapatkan dengan membagi net income dengan jumlah saham
beredar.Semakin besar nilai EPS, semakin menarik bagi investor. Beberapa faktor yang membuat nilai EPS naik, adalah (1) meningkatnya nilai net income dan jumlah saham tetap, atau (2) menurunnya jumlah saham beredar sedangkan net income tetap, atau (3) kenaikan net income bersamaan dengan penurunan jumlah saham beredar, atau (4) peningkatan net income dan jumlah saham beredar, dimana \% kenaikan net income lebih besar daripada \% peningkatan jumlah saham beredar.

Pada umumnya kondisi pertama yang sering terjadi, dikarenakan jumlah saham beredar yang relatif tetap.Dengan demikian peningkatan earning per share (EPS) menjadi sinyal yang positif.

\section{Return on Equity (ROE)}

Menurut Budy Frensidy (2017) rasioreturn on equity(ROE) juga menjadi salah satu rasio yang dijadikan pertimbangan bagi para investor.Rasio ini menunjukkan sumber pertumbuhan sebuah perusahaan.

$$
\text { RETURN ON EQUITY }=\frac{\text { NET INCOME }}{\text { TOTAL EQUITY }}
$$

Makin meningkatnya rasio $\mathrm{ROE}$ menunjukkan bahwa (1) net income perusahaan yang meningkat, sedangkan total equity yang relatif tetap, atau (2) total equity mengalami penurunan sedangkan net income tetap, atau (3) net income meningkat dan total equity menurun, atau (4) net income meningkat dan total equity juga meningkat, namun $\%$ peningkatan net income lebih besar dibandingkan \% peningkatan total equity.

Para investor tentu saja lebih memilih perusahaan yang memberikan ROE yang meningkat setiap tahun. Menurut Frensidy (2017) investor akan menghindari saham yang memiliki ROE di bawah $10 \%$ dan lebih berminat dengan saham-saham yang memiliki ROE diatas $20 \%$. 


\section{Net Profit Margin (NPM)}

Rasio net profit margin menghitung perbandingan $\%$ penjualan yang menghasilkan net income. Para analis dan investor akan kuatir jika rasio ini terlalu rendah.

$$
\text { NET PROFIT MARGIN }=\frac{\text { NET INCOME }}{\text { SALES }}
$$

Peningkatan rasio net profit margin dapat terjadi jika (1) net income meningkat, sedangkan sales tetap, atau (2) sales turun sedangkan net income tetap, atau (3) net income naik dan sales turun, atau (4) net income dan sales meningkat, namun \% kenaikan net income lebih besar daripada \% kenaikan sales. Skenario keempat menunjukkan bahwa perusahaan dapat melakukan cost efficiency yang baik, sehingga \% kenaikan net income lebih besar daripada $\%$ kenaikan sales.

\section{Harga Saham}

Motivasi bagi para investor dalam membeli saham adalah untuk menikmati keuntungan dalam bentuk deviden dan capital gain.

Harga saham tentunya menjadi acuan yang jelas bagi investor.Keuntungan dicapai ketika harga jual lebih besar daripada harga beli, dan demikian pula sebaliknya.Tentunya perhitungan ini harus memperhitungkan fee jual dan fee beli.

Saat ini harga saham di pasar regular Bursa Efek Indonesia, ditetapkan minimal sebesar Rp. 50 per lembar saham.Artinya saham yang diperdagangkan di pasar regular, memiliki batas bawah Rp. 50 per lembar saham. Investor yang melakukan transaksi dengan menginput harga saham dibawah Rp. 50 per lembar saham, akan secara otomatis ditolak oleh JATS (Jakarta Automatic Trading System).

\section{Model Penelitian Dan Pengembangan Hipotesis}

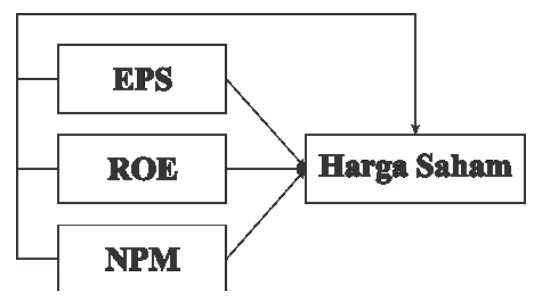

\section{Gambar 1 Model Penelitian}

$\mathrm{H}_{1}$ : Earning per Share (EPS)memiliki pengaruh terhadapharga saham

$\mathrm{H}_{2}$ : Return on Equity (ROE) memiliki pengaruh terhadapharga saham

$\mathrm{H}_{3}$ : Net Profit Margin (NPM) memiliki pengaruh terhadapharga saham

$\mathrm{H}_{4}$ : EPS, ROE dan NPMsecara bersamasama memiliki pengaruh terhadapharga saham

\section{Metode Penelitian}

\section{Jenis Penelitian}

Penelitian ini menggunakan metode penelitian asosiatif/hubungan, dimana penelitian ini bertujuan untuk mengetahui hubungan antara 3 variabel independen (EPS $<$ ROE dan NPM) terhadap 1 variabel dependen (harga saham).Menurut Siregar (2013) penelitian asosiatif merupakan penelitian yang bertujuan untuk mengetahui hubungan antara 2 atau lebih variabel.Diharapkan dari penelitian ini dapat dihasilkan teori yang dapat digunakan untuk menjelaskan, meramalkan dan mengontrol suatu kejadian.

\section{Operasionalisasi Variabel}

Penelitian dengan judul "Pengaruh Earning per Share (EPS), Return on Equity (ROE) dan Net Profit Margin (NPM) terhadap Harga Saham" memiliki variabel penelitian sebagai berikut: 
1. Variabel Independen (X)

Variabel independen adalah variabel bebas yang tidak akan dipengaruhi oleh variabel lain.

Terdapat 3 variabel independen dalam penelitian ini, yaitu:

$\mathrm{X}_{1}$ : Earning per Share (EPS)

$\mathrm{X}_{2}$ : Return on Equity (ROE)

$\mathrm{X}_{3}$ : Net Profit Margin (NPM)

Skala yang digunakan adalah rasio.

2. Variabel Dependen (Y)

Variabel dependen adalah variabel yang tidak bebas. Dengan kata lain variabel ini akan dipengaruhi oleh variabel lain.

Variabel dependen dalam penelitian ini adalah harga saham, yang diukur dariadjusted closing price per tanggal 31 Desember di Bursa Efek Indonesia. Skala variabel harga saham adalah rasio.

\section{Populasi dan Sampel}

Populasi yang digunakan dalam penelitian ini adalah perusahaan yangterdaftar dalam indeks IDX30 di Bursa Efek Indonesia, periode 2014 - 2017.

Sampel diambil dengan menggunakan metode purposive sampling.Menurut Siregar (2017) purposive samplinggmerupakan penetapan sampel berdasarkan kriteria tertentu.

Kriteria dalam menentukan sampel adalah sebagai berikut:

1. Saham perusahaan yang masuk dalam indeks IDX30 secara terus-menerus dari tahun 2014 sampai tahun 2017.

2. Laporan keuangan perusahaan tersedia dari tahun 2014 -2017.

Berdasarkan kriteria diatas, terdapat 19 perusahaan yang menjadi sampel dalam penelitian ini (Tabel 1).

\section{Tabel 1}

Daftar Nama Perusahaan dan Kode Saham yang Menjadi Sampel Penelitian

\begin{tabular}{|c|c|c|}
\hline No & \begin{tabular}{|c|} 
KODE \\
SAHAM \\
\end{tabular} & NAMA PERUSAHAAN \\
\hline 1 & $\mathrm{ADHI}$ & Adhi Karya(Persero) Tbk \\
\hline 2 & ADRO & Adaro Energy Tb k \\
\hline 3 & ASI & Astra Intemational $\mathrm{Tbk}$ \\
\hline 4 & $\mathrm{BBCA}$ & Bank Cental Asia Tbk \\
\hline 5 & BBHI & Bank Hegara Indones ia (Persero) Tbk \\
\hline 6 & BBRI & Bank Rakgat Indone ia (Persero) Tbk \\
\hline 7 & BMRI & Bank Mandiri(Pesero) Tbk \\
\hline 8 & GGRM & Gudamg Garam Tbk \\
\hline 9 & ICBP & Ind ofood CBP Sulses Malonur Thk \\
\hline 10 & INDF & Indofood Sulses Malmur Tbk \\
\hline 11 & INTP & Indocement Tunggal Prakasa Tbk \\
\hline 12 & $\mathrm{KLBF}$ & Kalbe Fama Tbk \\
\hline 13 & LPKR & Lippo Karawaci Tbk \\
\hline 14 & $\mathrm{MHCH}$ & Media Nusartara Citra Tbk \\
\hline 15 & PGAS & Perusahaam $\mathrm{G}$ a Negara(Persero) Tbk \\
\hline 16 & SMGR & Semen Indonesia (Pesero) $\mathrm{Tb} k$ \\
\hline 17 & TLKM & Telekomuriksi Indonesia(Pesero) Tbk \\
\hline 18 & UHTR & Urited Tractors Tbk \\
\hline 19 & UNVR & Urilever Indones ia Tbk \\
\hline
\end{tabular}

Sumber: Data sekunder yang diolah

\section{Teknik Pengumpulan Data}

Pengumpulan data dilakukan dengan cara sebagai berikut:

1. Data sekunder

Data sekunder diperoleh melalui web resmi Bursa Efek Indonesia (BEI), yaitu www.idx.co.id

2. Studi Pustaka

Penelitian ditunjang dengan mempelajari, mengkaji dan menelaah literatur-literatur, baik yang berupa berupa buku, jurnal, berita, dan artikel blog di internet yang berkaitan dengan masalah yang diteliti.

\section{Metode Analisis Data}

\section{Pengujian Asumsi Klasik}

\section{Uji Normalitas}

Uji normalitas digunakan untuk mengetahui apakah data sampel yang digunakan terdistribusi normal atau tidak.Uji yang digunakan dapat menggunakan Gambar 
Normal P-P Plot of Regression Standardized Residual.

Keputusan yang diambil jika menggunakan Gambar Normal P-P Plot of Regression Standardized Residual adalah sebagai berikut:

a. Jika data menyebar di sekitar garis diagonal dan mengikuti garis diagonal, maka data terdistribusi normal.

b. Jika data menyebar jauh dari garis diagonal dan tidak mengikuti garis diagonal, maka data tidak terdistribusi normal.

Model regresi yang baik, datanya terdistribusi normal.

\section{Uji Multikolinearitas}

Uji multikolinearitas adalah uji untuk melihat apakah ada hubungan antar variabel independen.Hubungan ini bisa dilihat pada Tabel Coefficients, dengan menghitung nilai:

a. Variance Inflation Factor (VIF), jika VIF $<10$ maka tidak terjadi multikolinearitas dan

b. Tolerance, dimana jika Tolerance $>0.1$ maka tidak terjadi multikolinearitas.

Model regresi yang baik, tidak terjadi korelasi antara variabel independen.

\section{Uji Autokorelasi}

Uji autokorelasi merupakan uji korelasi antara variabel yang diteliti, yang disusun berdasarkan waktu.Metode yang digunakan adalah Durbin Watson (DW Test).

Keputusan yang diambil jika menggunakan Durbin Watson (DW Test) adalah sebagai berikut:

a. $\mathrm{dU}<\mathrm{DW}<4$-dU $\rightarrow \mathrm{H}_{0}$ diterima, artinya tidak ada korelasi

b. $\mathrm{DW}<\mathrm{dL}$ atau $\mathrm{DW}>4-\mathrm{dL} \rightarrow \mathrm{H}_{0}$ ditolak, artinya terjadi autokorelasi.

c. $\quad \mathrm{dL}<\mathrm{DW}<\mathrm{dU}$ atau 4-dU $<\mathrm{DW}<$ $4-\mathrm{dL} \rightarrow$ artinya tidak ada kepastian atau kesimpulan yang pasti.
Model regresi yang baik, tidak menunjukkan adanya autokorelasi.

\section{Uji Heteroskedastisitas}

Uji heteroskedastisitas digunakan untuk mengetahui apakah dalam model regresi terdapat ketidaksamaan varian residu.Metode yang digunakan adalah metode gambar Scatterplot.

Keputusan yang diambil jika menggunakan Scatterplot adalah:

a. Jika titik-titik yang dihasilkan pada scatterplot membentuk pola tertentu (bergelombang, melebar, dan lain-lain) maka terjadi heteroskedastisitas.

b. Jika titik-titik yang dihasilkan pada scatterplot tidak membentuk pola yang jelas, seperti menyebar di atas atau di bawah angka 0 pada sumbu Y, maka tidak terjadi heteroskedastisitas.

Model regresi yang baik, tidak terjadi heteroskedastisitas.

\section{Pengujian Hipotesis}

\section{Analisis Persamaan Linear Berganda}

Analisis regresi berganda digunakan untuk menguji 2 atau lebih variabel independen terhadap satu variabel dependen.

Dalam penelitian ini, terdapat 3 variabel independen (EPS, ROE dan NPM) yang akan diuji terhadap variabel dependen (harga saham).

Persamaan regresi linear berganda adalah sebagai berikut:

$$
\mathbf{Y}=\mathbf{a}+\mathbf{b}_{1} \mathbf{X}_{1}+\mathbf{b}_{2} \mathbf{X}_{2}+\mathbf{b}_{3} \mathbf{X}_{3}+\mathbf{e}
$$

Dimana:

$\mathrm{Y}=$ harga saham

$\mathrm{a}, \mathrm{b}_{1}, \mathrm{~b}_{2}$ dan $\mathrm{b}_{3}=$ konstanta

$\mathrm{X}_{1}=$ Earning per Share (EPS)

$\mathrm{X}_{2}=$ Return on Equity (ROE)

$\mathrm{X}_{3}=\operatorname{Net}$ Profit Margin(NPM)

$\mathrm{e}=$ error

\section{Uji Parsial (Uji -t)}

Uji-t digunakan untuk melihat pengaruh variabel independen terhadap variabel 
dependen secara parsial. Perhitungan dilakukan dengan melihat ke dalam Tabel Koefisien Regresi/coefficient dengan kriteria sebagai berikut:

- Jika nilai signifikansi $<0.05 \rightarrow$ tolak $\mathrm{H}_{0}$, artinya ada pengaruh variabel independen terhadap variabel dependen.

- Jika nilai signifikansi $>0.05 \rightarrow$ terima $\mathrm{H}_{0}$, artinya tidak ada pengaruh variabel independen terhadap variabel dependen.

\section{Uji Simultan (Uji-F)}

Uji-F digunakan untuk melihat pengaruh variabel independen terhadap variabel dependen secara simultan. Perhitungan dilakukan dengan melihat ke dalam Tabel ANOVA dengan kriteria sebagai berikut:

- Jika nilai signifikansi dari masingmasing variabel independen $<0.05$ $\rightarrow$ tolak $\mathrm{H}_{0}$, artinya semua variabel independen secara Bersama-sama berpengaruh terhadap variabel dependen.

- Jika nilai signifikansi dari masingmasing variabel independen $>0.05$ $\rightarrow$ terima $\mathrm{H}_{0}$, artinya semua variabel independen secara bersam-sama tidak berpengaruh terhadap variabel dependen.

\section{Hasil Penelitian dan Pembahasan}

\section{Asumsi Klasik Analisis Regresi}

\section{Uji Normalitas}

Untuk menguji apakah data terdistribusi normal, penelitian menggunakan software SPSS ver. 23 untuk melakukan analisis Gambar Normal P-P Plot of Regression Standardized Residual.

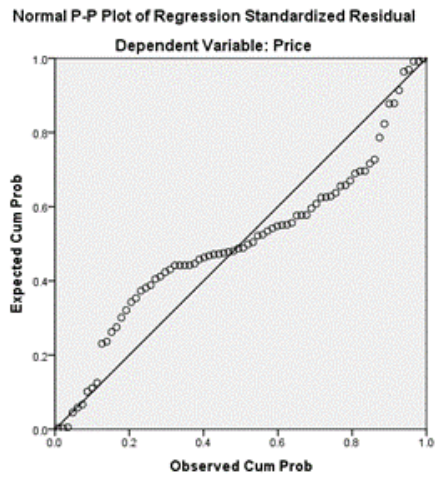

Gambar 2

Uji Normalitas

Hasil Uji Normalitas:

Dari gambar gambar Normal P-P Plot of Regression Standardized Residual, terlihat bahwa titik-titik menyebar mengikuti garis diagonal, maka nilai residu telah terdistribusi normal.

\section{Uji Multikolinearitas}

Hasil multikolinearitas dapat dilihat dari Variance Inflation Factor (VIF) dan nilai Tolerance. Dengan menggunakan software SPSS ver. 23, diperoleh tableCoefficients sebagai berikut:

Tabel 2

Uji Multikolinearitas

\begin{tabular}{|c|c|c|c|c|c|c|c|c|}
\hline \multicolumn{9}{|c|}{ Coefficients" } \\
\hline & & \multicolumn{2}{|c|}{$\begin{array}{l}\text { Urstandardized } \\
\text { Coefficients }\end{array}$} & \multirow{2}{*}{$\begin{array}{c}\begin{array}{c}\text { Standardized } \\
\text { Coefficients }\end{array} \\
\text { Beta }\end{array}$} & \multirow[b]{2}{*}{ t } & \multirow[b]{2}{*}{ Sig. } & \multicolumn{2}{|c|}{$\begin{array}{c}\text { Collinearity } \\
\text { Statastics }\end{array}$} \\
\hline \multicolumn{2}{|c|}{ Model } & B & Std. Error & & & & Toler ance & VIF \\
\hline 1 & (Constant) & .89 .335 & 132.958 & & .872 & 504 & & \\
\hline & EPS & 18.091 & .764 & .843 & 23.684 & 000 & .92 & 1.008 \\
\hline & ROE & 234.361 & 22.662 & .370 & 10.342 & 000 & .981 & 1.019 \\
\hline & NPM & .227 .241 & 60.617 & .134 & .3749 & 000 & .989 & 1.012 \\
\hline
\end{tabular}

Dari tabel diatas dapat dilihat bahwa nilai VIF semuanya di atas 10 dan nilai tolerance semuanya diatas 0.10.Jadi dapat disimpulkan bahwa tidak ada multikolinearitas dalam model regresi.

\section{Uji Autokorelasi}

Uji Durbin Watson (DW) dilakukan dengan menggunakan software SPSS ver. 23, dan diperoleh tabel Model Summary sebagai berikut: 


\section{Tabel 3}

Uji Autokorelasi - Model Summary

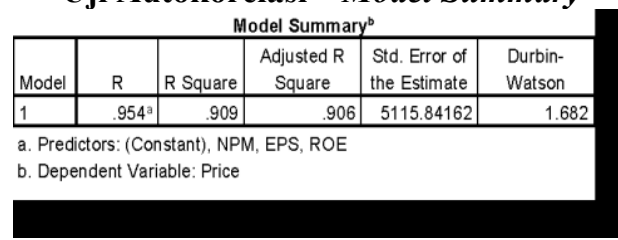

Dari tabel diatas terlihat bahwa Durbin Watson (DW) sebesar 1.682. Sedangkan dari tabel Durbin Watson dengan $\alpha=0.05$, $\mathrm{n}=76$ dan jumlah variabel independen $=3$, maka diperoleh nilai $\mathrm{dL}=1.5467$ dan $\mathrm{dU}=$ 1.7104. Hasil uji autokorelasi menunjukkan bahwa nilai DW (1.682) berada diantara $\mathrm{dL}$ (1.5467) dan dU (1,7104), sehingga tidak ada kesimpulan yang pasti.

\section{Uji Heteroskedastisitas}

Uji heteroskedastisitas dilakukan dengan menggunakan software SPSS ver. 23 dan diperoleh gambar Scatterplot, sebagai berikut:

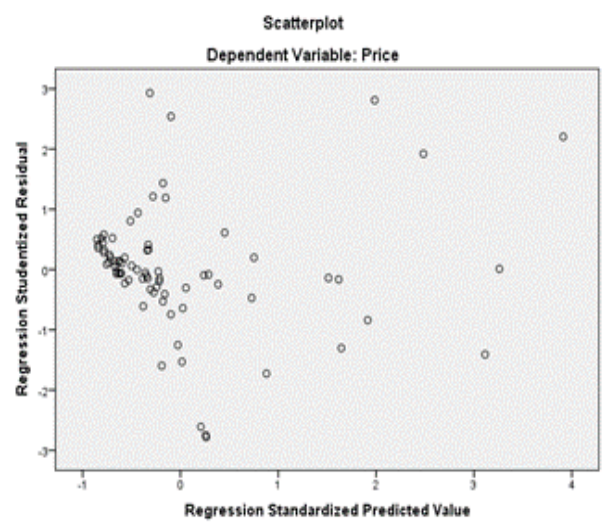

Gambar3

\section{Uji Heteroskedastisitas - Scatterplot}

Dari gambar diatas terlihat bahwa titik-titik yang dihasilkan pada scatterplot tidak membentuk pola yang jelas, seperti menyebar di atas atau di bawah angka 0 pada sumbu Y, maka tidak terjadi heteroskedastisitas.

\section{Pengujian Hipotesis}

Berdasarkan pengolahan data dengan menggunakan regresi berganda, dimana variabel dependen adalah harga saham $(\mathrm{Y})$ dan variabel independen adalah EPS $\left(\mathrm{X}_{1}\right)$, $\operatorname{ROE}\left(\mathrm{X}_{2}\right)$ dan NPM $\left(\mathrm{X}_{3}\right)$.

Model persamaan regresi berganda adalah sebagai berikut:

$$
\mathbf{Y}=\mathbf{a}+\mathbf{b}_{1} \mathbf{X}_{1}+\mathbf{b}_{2} \mathbf{X}_{2}+\mathbf{b}_{3} \mathbf{X}_{3}+\mathbf{e}
$$

Dengan menggunakan software SPSS ver. 23, diperoleh hasil sebagai berikut:

\section{Tabel 4}

Regresi Berganda

\begin{tabular}{|c|c|c|c|c|c|c|}
\hline \multicolumn{7}{|c|}{ Coefficients $^{3}$} \\
\hline & & $\begin{array}{r}\text { Unsta } \\
\text { Coe }\end{array}$ & $\begin{array}{l}\text { yardized } \\
\text { cients }\end{array}$ & $\begin{array}{c}\text { Standardized } \\
\text { Coefficients } \\
\end{array}$ & & \\
\hline \multicolumn{2}{|c|}{ Model } & B & Std. Error & Beta & $t$ & Sig. \\
\hline \multirow[t]{4}{*}{1} & (Constant) & -889.335 & 1322.959 & & -.672 & .504 \\
\hline & EPS & 18.091 & .764 & 843 & 23.684 & .000 \\
\hline & ROE & 234.361 & 22.662 & .370 & 10.342 & .000 \\
\hline & NPM & -227.241 & 60.617 & -.134 & -3.749 & .000 \\
\hline
\end{tabular}

Berdasarkan hasil tabel diatas, maka dapat dibentuk persamaan regresi berganda sebagai berikut:

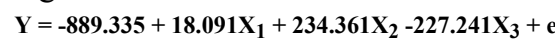

Dari persamaan regresi berganda diatas, dapat diartikan sebagai berikut:

- Nilai konstanta, a = -889,335 dapat diartikan bahwa jika variabel independen adalah 0 , maka nilai harga saham adalah -889.335 .

- Nilai koefisien $b_{1}=18,091$ dapat diartikan bahwa jika variabel EPS naik sebesar 1 satuan dan variabel lain tidak berubah, maka harga saham akan naik sebesar 18,091.

- Nilai koefisien $\mathrm{b}_{2}=234,361$ dapat diartikan bahwa jika variabel ROE naik sebesar 1 satuan dan variabel lain tidak berubah, maka harga saham akan naik sebesar 234,361.

- Nilai koefisien $b_{3}=-227,241$ dapat diartikan bahwa jika variabelNPM naik sebesar 1 satuan dan variabel lain tidak berubah, maka harga saham akan turun sebesar 227,241. 


\section{Pengujian Koefisien Regresi secara Parsial}

Untuk pengujian korelasi regresi parsial, tabel 4: Coeficient akan digunakan kembali. Selain itu untuk mengetahui seberapa besar pengaruh variabel independen terhadap variabel dependen, maka tabel berikut ini akan digunakan juga.

\begin{tabular}{|c|c|c|c|c|c|}
\hline \multicolumn{6}{|c|}{$\begin{array}{c}\text { Tabel } 5 \\
\text { Correlations } \\
\text { Correlations } \\
\end{array}$} \\
\hline & & EPS & $\mathrm{ROE}$ & NPM & Price \\
\hline \multirow[t]{3}{*}{ EPS } & Pearson Correlation & 1 & .087 & .002 & $.875^{\pi x}$ \\
\hline & Sig. (2-tailed) & & 452 & .986 & .000 \\
\hline & $N$ & 76 & 76 & 76 & 76 \\
\hline \multirow[t]{3}{*}{ ROE } & Pearson Correlation & .087 & 1 & .107 & $430^{x x}$ \\
\hline & Sig. (2-tailed) & .452 & & .360 & .000 \\
\hline & $N$ & 76 & 76 & 76 & 76 \\
\hline \multirow[t]{3}{*}{ NPM } & Pearson Correlation & .002 & .107 & 1 & -.092 \\
\hline & Sig. (2-tailed) & 986 & .360 & & .427 \\
\hline & N & 76 & 76 & 76 & 76 \\
\hline \multirow[t]{3}{*}{ Price } & Pearson Correlation & $.875^{x x}$ & $430^{m}$ & -.092 & 1 \\
\hline & Sig. (2-tailed) & .000 & .000 & .427 & \\
\hline & $N$ & 76 & 76 & 76 & 76 \\
\hline
\end{tabular}

\section{Pengaruh EPS terhadap Harga Saham}

Pengujian dengan menggunakan Uji-t dimana hipotesis pengujian adalah sebagai berikut:
$\mathrm{H}_{0}: \beta_{\mathrm{i}}=0$ EPS secara parsial tidak berpengaruhterhadap harga saham

$\mathrm{H}_{0}: \beta_{\mathrm{i}} \neq 0$ EPS secara parsial mempunyai pengaruhterhadap harga saham

Pada tabel 4: Regresi Berganda Coefficients, terlihat bahwa thitung sebesar 23,684 dan signifikansi 0,000. Sedangkan t tabel dengan signifikansi 0,05 , derajat kebebasan df $=\mathrm{n}-\mathrm{k}-1=76-3-1=72$, diperoleh hasil $t$ hitung sebesar 1,993.

Karena nilai $\mathrm{t}$ hitung $(23,684)>\mathrm{t}$ tabel $(1,993)$ dan signifikansi $0,000<0,05$, maka $\mathrm{H}_{0}$ ditolak. Hal ini menunjukkan bahwa EPS berpengaruh secara parsial terhadap harga saham.

Dari Tabel 5: Correlations terlihat bahwa koefisien determinasi parsial EPS terhadap harga saham sebesar $(0,875)^{2}=0,7656$ atau secara parsial EPS berpengaruh terhadap saham sebesar $76,56 \%$, sedangkan sisanya yaitu $23,44 \%$, dipengaruhi oleh variabel lain yang tidak dimasukkan dalam penelitan ini.

\section{Pengaruh ROE terhadap Harga Saham}

Pengujian dengan menggunakan Uji-t dimana hipotesis pengujian adalah sebagai berikut:

$\mathrm{H}_{0}: \beta_{\mathrm{i}}=0$ ROE secara parsial tidak berpengaruhterhadap harga saham

$\mathrm{H}_{0}: \beta_{\mathrm{i}} \neq 0$ ROE secara parsial mempunyai pengaruhterhadap harga saham

Pada tabel 4: Regresi Berganda Coefficients terlihat bahwa t hitung sebesar 10,342 dan signifikansi 0,000 . Sedangkan t tabel dengan signifikansi 0,05 , derajat kebebasan df $=\mathrm{n}-\mathrm{k}-1=76-3-1=72$, diperoleh hasil t hitung sebesar 1,993.

Karena nilai $\mathrm{t}$ hitung $(10,342)>\mathrm{t}$ tabel $(1,993)$ dan signifikansi $0,000<0,05$, maka $\mathrm{H}_{0}$ ditolak. Hal ini menunjukkan bahwa ROE berpengaruh secara parsial terhadap harga saham.

Dari Tabel 5: Correlations terlihat bahwa koefisien determinasi parsial ROE terhadap harga saham sebesar $(0,430)^{2}=0,1849$ atau secara parsial ROE berpengaruh terhadap saham sebesar $18,49 \%$, sedangkan sisanya yaitu $81,51 \%$, dipengaruhi oleh variabel lain yang tidak dimasukkan dalam penelitan ini.

\section{Pengaruh NPM terhadap Harga Saham}

Pengujian dengan menggunakan Uji-t dimana hipotesis pengujian adalah sebagai berikut:

$\mathrm{H}_{0}: \beta \mathrm{i}=0$ NPM secara parsial tidak berpengaruhterhadap harga saham

$\mathrm{H}_{0}: \beta \mathrm{i} \neq 0$ NPM secara parsial mempunyai pengaruhterhadap harga saham

Pada tabel 4: Regresi Berganda Coefficients terlihat bahwa thitung sebesar $-3,749$ dan signifikansi 0,000 . Sedangkan $t$ 
tabel dengan signifikansi 0,05 , derajat kebebasan $\mathrm{df}=\mathrm{n}-\mathrm{k}-1=76-3-1=72$, diperoleh hasil t hitung sebesar 1,993.

Karena nilai t hitung $(-3,749)<$-t tabel (1,993) dan signifikansi $0,000<0,05$, maka $\mathrm{H}_{0}$ ditolak. Hal ini menunjukkan bahwa NPM berpengaruh secara parsial terhadap harga saham.

Dari Tabel 5: Correlations terlihat bahwa koefisien determinasi parsial NPM terhadap harga saham sebesar $(-0,092)^{2}=0,008464$ atau secara parsial NPM berpengaruh terhadap saham sebesar $0,85 \%$, sedangkan sisanya yaitu $99,15 \%$, dipengaruhi oleh variabel lain yang tidak dimasukkan dalam penelitan ini.

\section{Pengujian Koefisien Regresi secara Simultan}

Pengujian dengan menggunakan Uji-F dimana hipotesis pengujian adalah sebagai berikut:

$\mathrm{H}_{0}: \beta \mathrm{i}=0$ EPS, ROE dan NPM tidak berpengaruhterhadap harga saham

$\mathrm{H}_{0}: \beta \mathrm{i} \neq 0$ EPS, ROE dan NPM mempunyaipengaruh terhadap harga saham

Pengujian dilakukan dengan menggunakan software SPSS ver. 23 dengan menggunakan Analisis Varians (ANOVA) dengan $\alpha=0,05$

Tabel 6

Pengujian Koefisien Regresi - ANOVA

\begin{tabular}{|c|c|c|c|c|c|c|}
\hline \multicolumn{7}{|c|}{ Sun of Souares } \\
\hline & & Sum of Squares & df & Mean Square & $\mathrm{F}$ & Sig. \\
\hline \multirow[t]{3}{*}{1} & Regression & 18927489409.910 & 3 & 6309163136.637 & 241.067 & $.000^{\circ}$ \\
\hline & Residual & 1884372151.077 & 72 & 26171835.432 & & \\
\hline & Total & 20811861560.987 & 75 & & & \\
\hline
\end{tabular}

a. Dependent Variable: Price

b. Predictors: (Corstant), NPM, EPS, ROE

Pada tabel 6 terlihat bahwa $\mathrm{F}$ hitung sebesar 241,067 dan signifikansi 0,000. Sedangkan $F$ tabel dengan signifikansi 0,05 , derajat kebebasan $\mathrm{df}_{1}=$ jumlah variabel $-1=3$ dan $\mathrm{df}_{2}=\mathrm{n}-\mathrm{k}-1=76-3-1=72$, diperoleh hasil $\mathrm{F}$ hitung sebesar 2,732.
Karena nilai $\mathrm{F}$ hitung $(241,067)>\mathrm{F}$ tabel $(2,732)$ dan signifikansi $0,000<0,05$, maka $\mathrm{H}_{0}$ ditolak. Hal ini menunjukkan bahwa EPS, ROE dan NPM secara bersama-sama berpengaruh terhadap harga saham.

Dari Tabel 3: Uji Autokorelasi - Model Summary, terlihat bahwa besarnya pengaruh variabel EPS, ROE dan NPM terhadap harga saham dalam indeks IDX30 yang tercatat di BEI tahun 2014-2017 adalah sebesar 90,6\%. Masih terdapat 9,4\% variabel lain diluar variabel EPS, ROE dan NPM yang berpengaruh terhadap harga saham.

\section{Simpulan dan Saran}

\section{Simpulan}

Berdasarkan hasil pengujian hipotesis diatas, maka dapat dibuat kesimpulan untuk menjawab permasalahan dalam penelitian ini:

1. EPS, ROE dan NPM berpengaruh terhadap harga saham perusahaan yang berada dalam Indeks IDX30 selama periode $2014-2017$

- Variabel EPS berpengaruh secara parsial terhadap harga saham, yaitu sebesar 76,56\%.

- Variabel ROE berpengaruh secara parsial terhadap harga saham, yaitu sebesar $18,49 \%$.

- Varibel NPM berpengaruh secara parsial terhadap harga saham, yaitu sebesar $0,85 \%$.

2. Variabel EPS, ROE dan NPM secara bersama-sama berpengaruh terhadap harga saham, yaitu sebesar 90,6\%.

\section{Saran}

Berdasarkan hasil penelitian di atas, peneliti menyarankan bagi peneliti selanjutnya agar:

1. Penelitian berikutnya tidak hanya terbatas pada perusahaan yang saham terdapat dalam indeks IDX30.

2. Pemilihan saham sektoral diharapkan bisa mempertajam analisis dan memberikan masukan pada sektor yang lebih spesifik. 
3. Selain itu penambahan rentang waktu yang lebih lama, tentunya akanmembuat hasil yang diperoleh akan lebih akurat.

\section{Daftar Pustaka}

Agustina, Lidya\&Sany Noviri (2013). Pengaruh Return on Asset (ROA), Earning per Share (EPS), dan Net Profit Margin (NPM) terhadap Harga Saham: Studi pada Indeks LQ45 Tahun 2010,Jurnal Akuntansi, Mei, Vol. 5,No. 1,Hal. 72-90.

Atmaja, Lukas Setia\&Thomdean.(2011). Who wants to be a SmilingInvestor.Edisi Kelima. Jakarta: Kepustakaan Populer Gramedia.

Brigham, Eugene \& Joel Houston.(2006). Manajemen Keuangan.Edisi kesepuluh. Terjemahan Dodo Suharno, Herman Wibowo. Jakarta: Erlangga.

Chan, Ronald W. (2012).The Value Investors. Edisi pertama.Erjemahan Generesius Blomen Nomer.Jakarta: PT Elex Media Komputindo.

Darmadji. (2001). Pasar Modal di Indonesia: Pendekatan Tanya Jawab. Edisi Pertama. Jakarta: Salemba Empat.

Filbert, Ryan. (2017). Yuk Belajar Nabung Saham, cetakan ke empat. Jakarta: PT Elex Media Komputindo.

Frensidy, Budi. (2016). Gesit dan Taktis di Pasar Modal: Berbekal Behavioral Finance, cetakan pertama. Jakarta: Salemba Empat.

Gunawan, Imam. (2016). Pengantar Statistika Inferensial, Edisi Pertama.Jakarta: Rajawali Pers.

Hartono, Jogiyanto. (2015). Teori Portofolio dan Analisis Investasi, Edisi Kesepuluh. Yogyakarta: BPFE UGM.

Jeany, Giacinta C.\&Lauw Tjun Tjun (2016). Pengaruh Current Ratio
(CR), Eaning per Share (EPS), dan Price Earning Ratio (PER) terhadap Harga Saham: Studi pada Perusahaan yang Terdaftar di Bursa Efek Indonesia Periode 2012-2014, Jurnal Akuntansi, Mei, Vol. 8,No. 1,Hal. 131-156.

Priyatno, Duwi. (2017). Panduan Praktis Olah Data menggunakan SPSS.Edisi pertama.Yogyakarta: CV. Andi Offset.

Samsul, Mohamad. (2015).Pasar Modal \& Manajemen Portofolio.Edisi ke dua.Jakarta: Erlagga.

Siregar, Syofian. (2017). Metode Penelitian Kuantitatif.Edisi ke empat.Jakarta: Kencana.

Tandelilin, Eduardus. (2001). Analisis Investasi dan Manajemen Portofolio.Edisi pertama. Yogyakarta: BPFE.

\section{Internet:}

www.idx.co.id. 